\title{
An Analysis of Workload and Worker's Complaint In Tofu Industry
}

\author{
Meri Andriani ${ }^{1}$, Muhammad Thaib Hasan ${ }^{1}$, Rizalul Akram $^{2}$, Cut Ita Erliana ${ }^{3}$ and Zulmiardi ${ }^{4}$ \\ \{meri_tind@unsam.ac.id\}

\begin{abstract}
${ }^{1}$ Department of Industrial Engineering, Universitas Samudra, Langsa, Indonesia
${ }^{2}$ Department of Informatics Engineering, Universitas Samudra, Langsa, Indonesia

${ }^{3}$ Department of Industrial Engineering, Universitas Malikussaleh, Aceh Utara, Indonesia
\end{abstract} \\ ${ }^{4}$ Department of Mechanical Engineering, Universitas Malikussaleh, Aceh Utara, Indonesia
}

\begin{abstract}
Tofubusiness is a business that always done by manual material handling. The study aims to identify the workload and complaints on the tofu business. The research method is standard nordiqquestinnaire used to identify the point of the workercomplaint, biomechanics and REBA to identify workload done by the worker, anthropometry and percentile used to design, statistic test used to process anthropometry data, excel software used for data calculation anthropometry and percentile, auto cad software is used to create research designs. Result of the discussion that standard nordiq questionnaire have 26 point of complaint, REBA get three workers with action level 3, biomechanics used is maximum permissible limit got result with mean of force equal to 8676,36 $\mathrm{N}$. The conclusion of standard nordiq questionnaire identifies 26 complaints of pain and rather ill, REBA identifies that three workers with a high risk level so that the workload is large, the MPL identifies that all workers have a large workload so that the activity is dangerous. Workload is minimized by ergonomic work station design and lay-out.
\end{abstract}

Keywords: Anthropometric, biomechanics, design, rapid entire body assissment, workload.

\section{Introduction}

Tofu business is a business that all operator activity is done manually material handling and not ergonomic. Incorrect manual handling material handling (MMH) may result in an accidental loss to employees. Musculoskeletal complaints is one of uncorrect activity caused from the consequences of MMH activity [1].

Musculoskeletal complaints on the parts of skeletal muscle felt by someone strat from very mild to very sick complaints [2]. Without realizing that the activity of removal goods which was done by the workers can cause disease or injury to the spine especially if the work is not done properly [3].

Observation results that workers often lifting weights without assisted by the tool, the load raised is a container that has been filled with soybean material that has been mashed with a weight of $\pm 50 \mathrm{~kg}$.The fine soybeans are removed by means of lifting to the boiling site at a distance of seven meters, this is due to the location of all irregular workstations.

The location of irregular workstation causes the workers to do an activity lifting manually is not ergonomic and done repeatedly. Workers who perform activities with repetitive cycles are particularly susceptible to musculoskeletal disorders [4]. 
In addition to the location of work stations that do not fit the process sequence, soybean milling machine is so low that workers bending over to pick up smooth soybeans containers, and activity is repeated. Bending attitude is a non-ergonomic work attitude. If repeated and long periods of time will cause musculoskeletal disorders.

This observations do in the field it was known that the activities of workers in the tofu business done for 10 hours, even more during Ramadan, this is a huge workload for the workers. They also complain that the upper body is sick and tired.Huge workloads and complaints from workers are the issues that will be investigated with ergonomics.

\section{Literature Review}

\subsection{Ergonomi}

Ergonomics can be defined asthe study of human aspects withinits work environment is reviewed anatomically, physiology, psychology, engineering, management and design [5].

\subsection{Standard Nordiq Quetionnaire}

Thestandard nordiq questionnaire is a tool used to identify the complaints on 28 sections. Pain sore point on posture is found in table1.

Table 1. This caption has one line so it is centered.

\begin{tabular}{|c|l|c|l|}
\hline No & \multicolumn{1}{|c|}{ Type of complaint } & No & \multicolumn{1}{|c|}{ Type of complaint } \\
\hline 0 & Rigid pain in the upper neck & 14 & Pain on the left wrist \\
\hline 1 & Rigid pain in the lower neck & 15 & Pain on right wrist \\
\hline 2 & Pain in the left shoulder & 16 & Pain in the left hand \\
\hline 3 & Pain in the right shoulder & 17 & Pain on the right hand \\
\hline 4 & Upper left arm pain & 18 & Pain in the left thigh \\
\hline 5 & Pain in the back & 19 & Pain in the right thigh \\
\hline 6 & Upper right arm pain & 20 & Pain in the left knee \\
\hline 7 & Pain at the waist & 21 & Pain in the right knee \\
\hline 8 & Pain on the buttocks & 22 & Pain in the left calf \\
\hline 9 & Pain in the butt & 23 & Pain in the right calf \\
\hline 10 & Pain on the left elbow & 24 & Pain in the left ankle \\
\hline 11 & Pain on the right elbow & 25 & Pain in the right ankle \\
\hline 12 & Pain in the left forearm & 26 & Pain on the left leg \\
\hline 13 & Pain in the right forearm & 27 & Pain in the right leg \\
\hline
\end{tabular}


Table 1 shows that 28 points of complaint including the point of complaint 0 is a type of upper stiff on upper neck. Through the questionnaire it can be seen that the parts muscles has complaint with the level of complaints start from not sick (NS), Rather Sick (RS), Sick (S), and Very Sick (VS) [6].

\subsection{Rapid Entire Body Assesment}

In the beginning rapid entire body assesment was originally developed to assess posture in the health care industry [7].

Rapid entire body assesment is a method for identifying disorders that occur in the overall posture. In the rapid entire body assesment method, body segments are divided into group A and group B. Group A isthe back, neck and legs. Group B is the upper arm, lower arm and wrist. The determination of the rapid entire body assesment score, begins with determining the A score for the group A postures plus the load score and B score for the group postures B plus the coupling score[8]. Score C obtained after score A and score B is determined. rapid entire body assesment scores are obtained by adding activity scores on score $\mathrm{C}$.

\subsection{Biomechanics}

Biomechanics in the measurement is done by two methods namely MPL (Maximum Permissible Limit) and RWL (Recommended Weigh Limit), research done using MPL method. In Method of MPL data used is the weight of burden, human weight as worker. The calculations are performed by calculating the forces that occur in the palms of the hands, lower arms, upper arms and back. The calculation results will be obtained compressive force (Fc) on theL5/S1. The standard given by MPL method is the large compressive force under $6500 \mathrm{~N}$ at L5/S1 while the limit of normal lifting force (the action limit) is $3500 \mathrm{~N}$ at L5/S1, so the standard is as follows [9]:

- If $\mathrm{Fc}<\mathrm{Al}$ (safe)

- If $\mathrm{Al}<\mathrm{Fc}<\mathrm{MPL}$ (need to be careful)

- If $\mathrm{Fc}>\mathrm{Al}$ (dangerous)

\subsection{Anthropometry and Percentiles}

The design is done to lay a soybean machine so that workers can work ergonomically, based on anthropometry.

Anthropometry studies the appropriateness of tool dimensional or machine with the body dimensions.Procedures that can be followed in the application of anthropometric data on the design process [10] is:

- Determine the user population of product design or work station. Different people in the age group will have different physical characteristics and needs, as well as forgender, race, ethnic group, civilian or military group;

- Determine the body dimensions that are thought to be important in design;

- Select the percentage of the population to be accommodated in the design;

- For each body dimension determine the relevant percentile value;

- Give looseness to existing data if necessary.

- Use simulators to test the design. The designers need to evaluate whether the design is appropriate or not;

Calculation of anthropometric data used is: 
- Unity data antropometry test.

$\mathrm{UCL}=X+\mathrm{k} \sigma$

$$
\mathrm{LCL}=X-\mathrm{k} \sigma
$$

Information :

UCL $=$ Upper Control Limit

LCL $=$ Lower ControlLimit

$\mathrm{k} \quad=$ Confidence Level $(95 \%)=2$

- Antropometric data adequacy test.

Information :

$$
N^{\prime}=\left[\frac{k / s \sqrt{N \sum X^{2}-\left(\sum X\right)^{f}}}{\sum X}\right]^{2}
$$

$S=$ Level of accuracy $(5 \%)$

$N=$ Amount of data needed

$N^{\prime}=$ Number of observation done

If $N^{\prime} \leq N$ then the data considered enough ;

If $N^{\prime} \geq N$ then the data is considered not enough (less) need to add data.

The percentile used to design is the 50th percentile by reason of its general use.

\section{Method}

The study was conducted for 3 weeks with the object of research is five business tofu operators who perform activities to lift the soybean with $50 \mathrm{~kg}$ weight to the boiling place. The instrument used is the camera to see the work posture, body ruler to measure workers' body dimensions, standard nordiq questionnaire to see the point of complaint on the worker's body.

Stages in the research that starts from looking at work posture when the workers do activities and retrieve data body dimensions of workers and provide standard nordiq questionnaire. After the data obtained then the data is done by using standard nordiq questionnaire, rapid entire body assesment, maximum permissible limit, anthropometry and percentile methods. Device design is done after anthropometry and percentile are obtained. While the design lay out done after making observations. The results of rapid entire body assesment and maximum permissible limit can be seen the amount of workload of workers.

\section{Result}

\subsection{Standard Nordiq Quesionnaire}

The standard nordic questionnaire is used to see the point of complaint to workers. The results of the standard assessment of the questionnaire obtained almost all the worker's body experiencing pain complaints. 


\subsection{Rapid Entire Body Assessment}

Workers in the work are assessed using the rapid entire body assessment. The assessment is conducted for five workers, contained in recapitulation table 2.

Table 2. Recapitulation of table A, B, C at rapid entire body assessment

\begin{tabular}{|c|c|c|c|}
\hline Worker & A & B & C \\
\hline Worker 1 & 8 & 3 & 9 \\
\hline Worker 2 & 4 & 3 & 5 \\
\hline Worker 3 & 6 & 3 & 7 \\
\hline Worker 4 & 6 & 5 & 9 \\
\hline Worker 5 & 7 & 4 & 9 \\
\hline
\end{tabular}

Table 2. shows that of rapid entire body assessment for worker 1 gets table $\mathrm{A}$ is 8 , table $\mathrm{B}$ is 3 and table $\mathrm{C}$ is 9 .

\subsection{Biomechanic}

Workers are assessed using the maximum permissible limit.The recapitulation of abdominal pressure (AP), stomach style (SS) and muscle style (MS) is shown in table 3.

Table 3. Recapitulation of maximum permissible limit

\begin{tabular}{|l|c|c|c|}
\hline Worker & $\mathrm{AP}\left(\mathrm{N} / \mathrm{m}^{2}\right)$ & $\mathrm{SS}(\mathrm{N})$ & Ms (N) \\
\hline Worker 1 & 0,42 & 197,54 & 6383,80 \\
\hline Worker 2 & 0,11 & 49,44 & 8034,26 \\
\hline Worker 3 & 0,09 & 41,03 & 6368,85 \\
\hline Worker 4 & 1,27 & 591,66 & 9064,49 \\
\hline Worker 5 & 0,52 & 240,25 & 9653,69 \\
\hline
\end{tabular}

Table 3 shows that worker 1 with abdominal pressure (AP) is worth $0.42 \mathrm{~N} / \mathrm{m}^{2}$, stomach style (SS) is worth $197,54 \mathrm{~N}$ and muscle style (MS) is worth $6383,80 \mathrm{~N}$.

\subsection{Layout Actual}

The result of observation to the field there is workstations that do not fit the process sequence, shown that Figure 1.

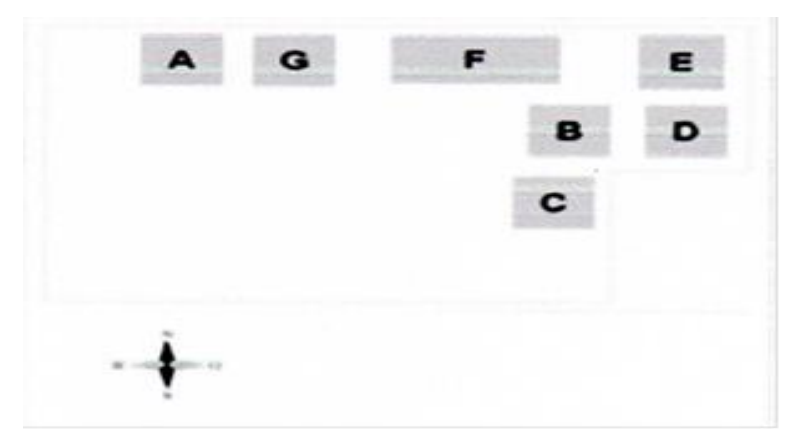

Figure 1. Layout the actual. 
Figure 1. shows that the layout of the workstation is not in the order of the process. The working station in tofu business is A. for station frying pan of tofu; B for soybean milling machine; $\mathrm{C}$ for soy washing station; $\mathrm{D}$ for soybean boiling station; $\mathrm{E}$ for filtration station; $\mathrm{F}$ for tofu printing station and G. for tofu cutting station.

\section{Discussion}

\subsection{Standard Nordiq Quesionnaire}

Workload Workers in the activity using manual material handling, while the load lifted by \pm $50 \mathrm{~kg}$ and repetitive, so that workers complain of pain in some parts of the body. SNQ questionnaire is used to see how many points of complaint on the worker's body.Questionnaire results are known there are 25 points of complaint that perceived workers are shown is found in table 4 .

Table 4. Recapitulation of standard nordiq questionnaire.

\begin{tabular}{cc}
\hline Worker & Complaint (\%) \\
\hline Worker 1 & 80,00 \\
\hline Worker 2 & 82,35 \\
\hline Worker 3 & 63,64 \\
\hline Worker 4 & 80,00 \\
\hline Worker 5 & 75,68 \\
\hline
\end{tabular}

Table 4 shows that worker 1 with $80 \%$ complaints, worker 2 with 82,35\% with complaints, worker 3 with $63,64 \%$ complaints, worker 4 with $80 \%$ complaints, worker 5 with 75,68\% complaints.

\subsection{Rapid Entire Body Assessment}

Rapid Entire Body Assessment (REBA) is used to assess the workload of five workers on tofu business. Recapitulation of workload assessment is found in table 5.

Table 5. Recapitulation of REBA methods

\begin{tabular}{cccc}
\hline Worker & Level of action & Level of risk & Action \\
\hline Worker 1 & 3 & High & Soon \\
\hline Worker 2 & 2 & Medium & Need \\
\hline Worker 3 & 2 & Medium & Need \\
\hline Worker 4 & 3 & High & Soon \\
\hline Worker 5 & 3 & High & Soon \\
\hline
\end{tabular}

Table 5 shows that there are three workers with high-risk level and immediate action are workers 1, 4 and 5. While worker 2 and worker 3 have medium risk level so action is needed. 


\subsection{Biomechanic}

Workload assessment can also be done using biomechanical methods. The biomechanics used is the MPL (Maximum Permissible Limit) method.

Recapitulation of workload assessment using MPL method is found in table 6.

Table 6. Recapitulation of MPL method

\begin{tabular}{cccl}
\hline Workers & Fc & MPL & Conclusion \\
\hline 1 & 6652,99 & 6500 & Dangerous \\
\hline 2 & 8547,87 & 6500 & Dangerous \\
\hline 3 & 8900,83 & 6500 & Dangerous \\
\hline 4 & 9192,57 & 6500 & Dangerous \\
\hline 5 & 10087,55 & 6500 & Dangerous \\
\hline
\end{tabular}

Table 6 shows that the activity in lifting containers filled with fine soybeans is an activity with large and dangerous loads.

\subsection{Anthropometry}

The design undertaken is the design of machine work stations and lay out. The design of machine work stations is based on the anthropometry method. Machine work stations designed according to the workers dimension. The employed dimension is the dimension of hand coverage to determine the widthof the base of the fine soybean container, the knee height dimension is used to determine the height of the soy container base, the height of the standing elbow is used to determine the soybean grinder base. Data of anthropometric dimension was done by statistical test that is data uniformity test and data adequacy test. Recapitulation of uniformity test for knee height dimension is found in figure 2.

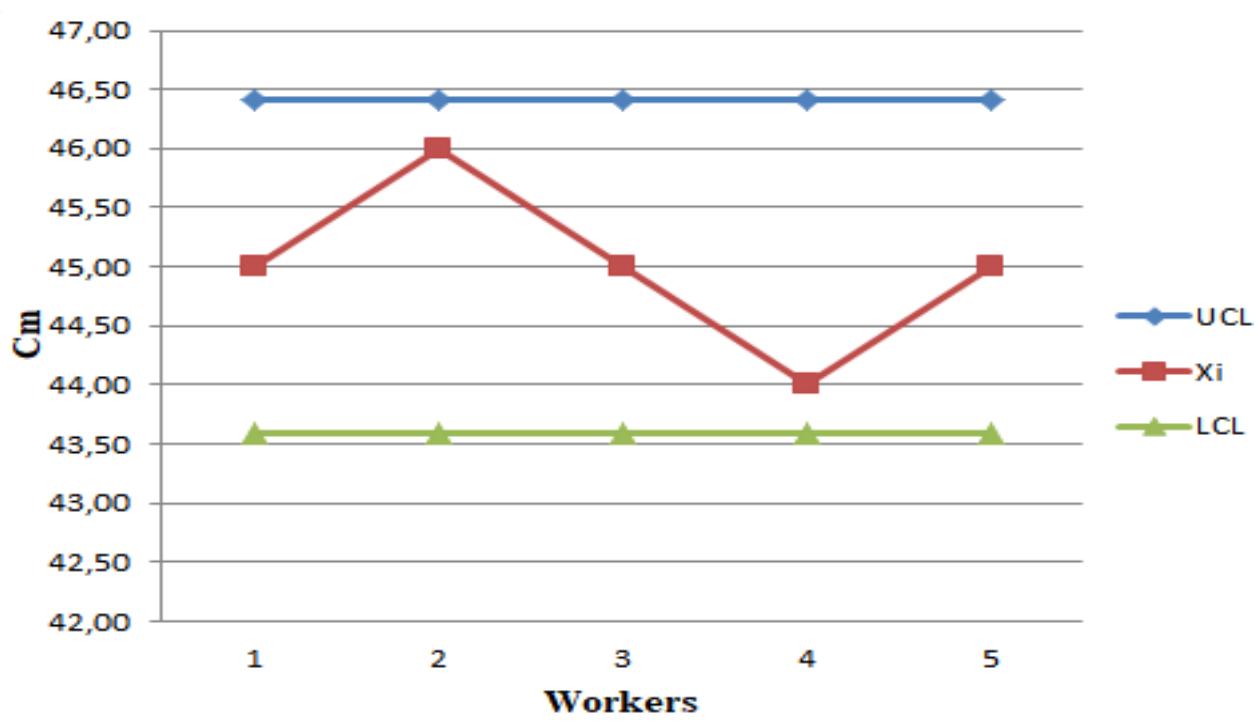

Figure 2. Recapitulation map of knee high dimension control 
Figure 2 shows that knee height dimension for all data is between the control limits, meaning all uniform data, such as worker 1 have with knee height dimension $45 \mathrm{~cm}$, dimension of worker 1 are between UCL is worth $46.41 \mathrm{~cm}$ and LCL is $43.59 \mathrm{~cm}$. The recapitulation of data adequacy test is found in table 7 .

Table 7. Recapitulation of data adequacy test.

\begin{tabular}{lccc}
\hline Dimension & $N$ & $N^{\prime}$ & Conclussion \\
\hline Range Hand & 5 & 1,23 & Enough \\
\hline Height knee & 5 & 0,30 & Enough \\
\hline Standing Tall Elbow & 5 & 0,86 & Enough \\
\hline
\end{tabular}

Table 7 shows that for knee height dimensions with $\mathrm{N}$ 'worth 0.30 under $\mathrm{N}$ data of 5 , it means enough data for designing work stations. The percentile used for the work station design is the 50th percentile, the percentile recapitulation is found in table 8.

Table 8. 50th percentile recapitulation.

\begin{tabular}{lc}
\hline Dimension & Persentil 50 \\
\hline Range Hand & 80,20 \\
\hline Height Knee & 45,00 \\
\hline Standing Tall Elbow & 104,40 \\
\hline
\end{tabular}

Table 8 shows that the 50th percentile for knee height dimension is 45.00 which is used as the basis for the width of the fine soybean container. Work station design is found in figure 3 .

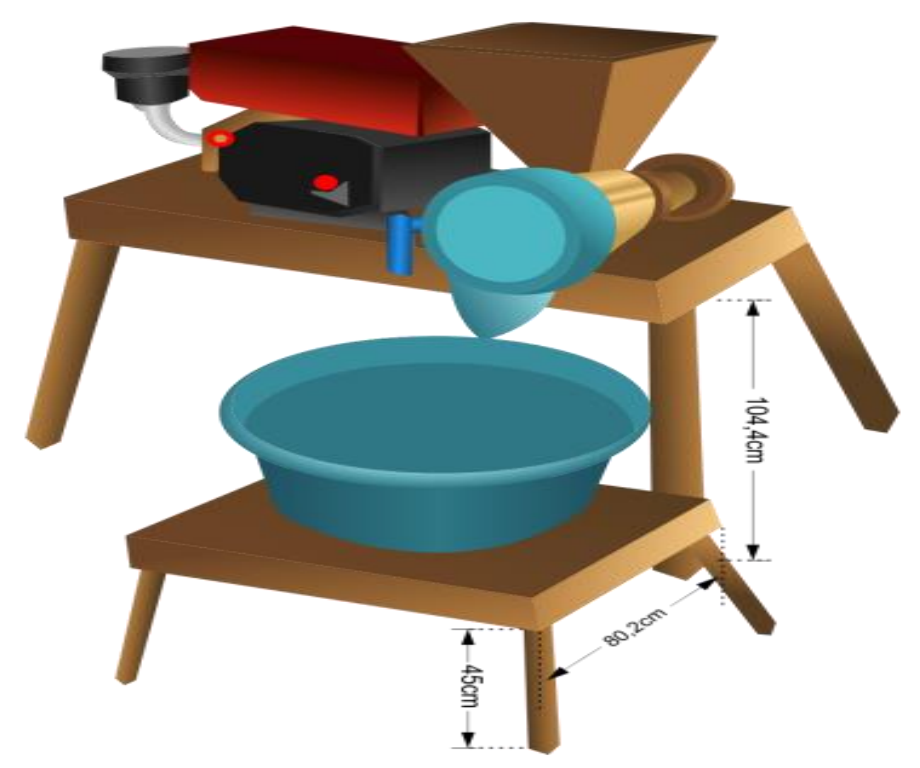

Figure 3. Desiging Work Station 
Figure 3 shows that the height of softcoy container table based on knee height is $45,00 \mathrm{~cm}$, table width of soybean container based on the dimension of hand reach that is $82 \mathrm{~cm}$, height of soybean machine table based on height height of elbow stand that is $102 \mathrm{~cm}$. Workstation design is expected to change worker's attitude, from a bent position to a standing position. The design of lay out in tofu business is done on the grounds the lay out that already exists, the location of the work station is not similar so that workers in the activities raised to another work station to be far away. Remote lifting activities and large loads make the activity no ergonomic. The layout design is found in Figure 4.

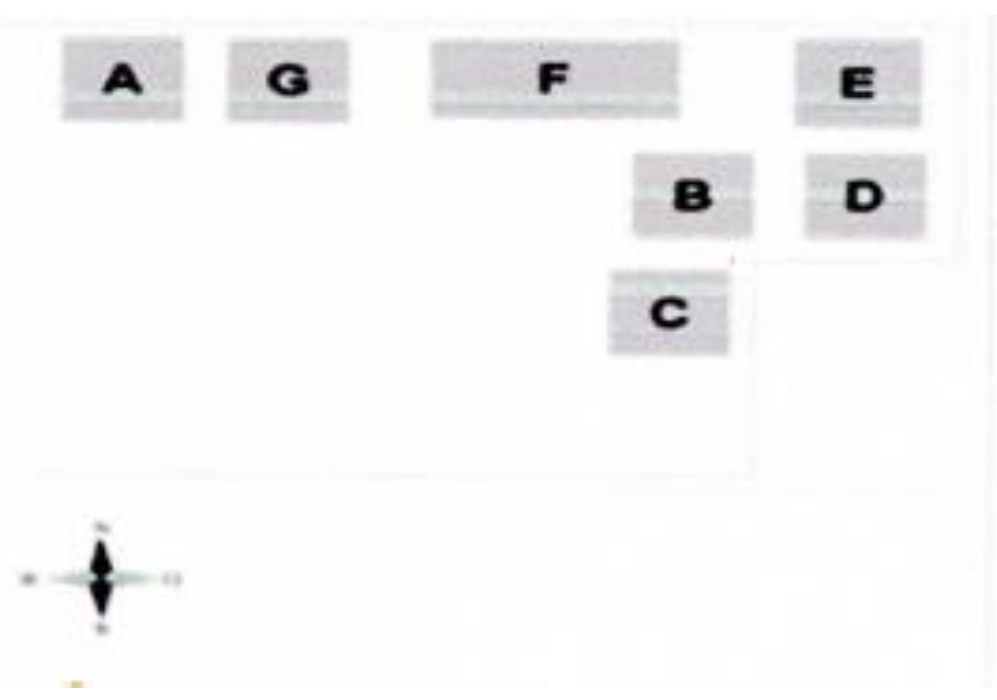

Figure 4. Designing ergonomics layout

Figure 4 shows that the location of all work stations was designed in accordance with the production process.

\section{Conclussion}

The based on the research it can be conclude:

- Standard nordiq questionnaire (SNQ) identifies that there are 26 point complaints ranging from mild to sick;

- REBA identifies that three workers with immediate category of action are taken because of high risk levels, while two workers with the category need to take action because of the level of risk being;

- The MPL identifies that all workers to engage in dangerous activities because the force of all workers exceeds the standard which applied;

- The design soybean milling machine is done to minimize manual handling material handling and work ergonomically;

- The design of lay-out is done to minimize the point of workers complaints and workload. 


\section{Acknowledgments.}

The authors would like to express their thanks to Samudra University (UNSAM) for the opportunity provided to the authors to carry out this research and for funding.

\section{References}

[1] Andriani, M. (2016), Perancangan peralatan secara ergonomi untuk meminimalkan kelelahan di pabrik kerupuk, Prosiding Seminar Nasional Sains dan Teknologi Fakultas Teknik Universitas Muhammadiyah Jakarta. November, pp. 1-10.

[2] Andriani, M. and Dewiyana. (2015), Analisa Subyektifitas dan Beban Kerja Secara Ergonomi Untuk Meningkatkan ProduktivitasJurutera. pp 6-10.

[3] Budiman, E. and Setyaningrum, R. (2006), Perbandingan Metode-metode Biomekanika untuk Menganalisis Postur pada Aktivitas Manual Material Handling (MMH), pp. 46-52.

[4] Hasibuan, M., Industri, D.T., Teknik, F., Utara, U.S. and Disorder, M. (2014), Analisis Keluhan Rasa Sakit Pekerja Dengan Menggunakan Metode Reba Di Stasiun Penjemuran, Vol. 1 No. 1, pp. $18-22$.

[5] Mas'idah, E., Fatmawati, W. and Ajibta, L. (2009), Analisa Manual Material Handling (MMH) dengan Menggunakan Metode Biomekanika Untuk Mengidentifikasi Resiko Cidera Tulang Belakang (Musculoskeletal Disorder), Universitas Sultan Agung, pp. 37-56.

[6] Muslimah, E., Teknik, J., Universitas, I., Surakarta, M., Pratiwi, I., Rafsanjani, F. and Masalah, L.B. (2006), Analisis Manual Material Handling,Jurnal Ilmiah Teknik Industri, Vol. V No. 2, pp. 53-60.

[7] Nurhasanah, E. and Mauluddin, Y. (2016), Perancangan Fasilitas Kerja Yang Ergonomis Dengan Pendekatan Rapid Entire Body Assessment Pada Pekerja Home Industry Pembuatan Tempe, Vol. 14, pp. 94-100.

[8] Restuputri, D.P. and Lukman, M. (2017), Metode REBA Untuk Pencegahan Musculoskeletal Disorder Tenaga Kerja, Jurnal Teknik Industri, Vol. 18 No. 1, pp. 19-28.

[9] Sareng, M.D.Y., Oesman, T.I. and Susetyo, J. (2016), Redesign keranjang sampah berdasarkan pendekatan ergonomi dengan menggunakan data antropometri untuk mengurangi cedera FISIK pada pemulung, Sareng Monika D.Y., Vol. 4 No. 2, pp. 60-118.

[10] Sutrio and Firdaus, O.M. (2011), Analisis Pengukuran RULA dan REBA Petugas pada Pengangkatan Barang di Gudang dengan Menggunakan Software Ergolntelligence (Studi kasus : Petugas Pembawa Barang di Toko Dewi Bandung), Prosiding Seminar Nasional Ritektra, pp. 203210. 